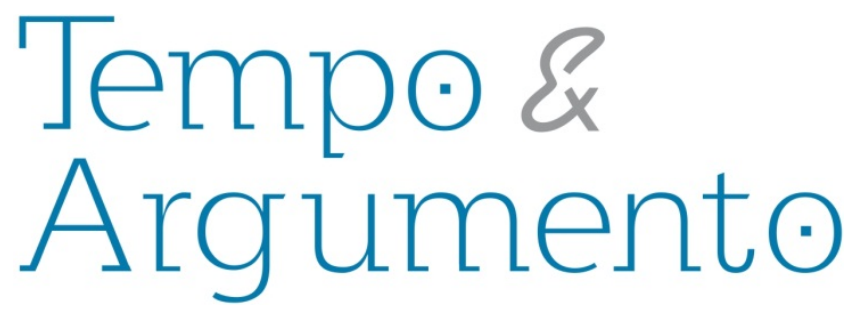

\title{
À Sombra do Precursor: produção e recepção da obra O Negro no Pará, de Vicente Salles ${ }^{1}$
}

\begin{abstract}
Resumo
Este artigo objetiva analisar o contexto de produção e a recepção da clássica obra O Negro no Pará sob o regime da escravidão, lançada por Vicente Salles (1931-2013) em 1971, a partir da premissa de que a compreensão de um intelectual polígrafo como Salles pode ser interpretada através de momentos-chave, e não necessariamente lineares, de sua trajetória profissional, como sugere Pierre Bourdieu. Trajetória, esta, assentada nos estudos sobre o negro, o folclore e a música na Amazônia. Lançando mão da teoria de Stuart Hall sobre a recepção, as formas comunicativas e as práticas discursivas sobretudo a relação entre o produtor-codificador e os receptoresdecodificadores -, analisa-se um conjunto diversificado de fontes como as cartas trocadas por Vicente Salles com outros intelectuais paraenses, jornais e entrevistas realizadas com o intelectual ora examinado.
\end{abstract}

Palavras-chave: O Negro no Pará; Vicente Salles; Intelectuais Amazônia; Produção-Codificação; Recepção-Decodificação.

\section{Para citar este artigo:}

MAFRA, Alessandra. À Sombra do Precursor: produção e recepção da obra O Negro no Pará, de Vicente Salles. Revista Tempo e Argumento, Florianópolis, v. 8, n. 18, p. 317 - 350. maio/ago. 2016.

DOI: $10.5965 / 2175180308182016317$

http://dx.doi.org/10.5965/2175180308182016317

\footnotetext{
${ }^{1}$ Este artigo representa uma versão revisada do terceiro capítulo da dissertação de mestrado 0 arauto da cultura paraense: uma história intelectual de Vicente Salles, defendida no Programa de Pós-Graduação em História da Universidade Federal do Pará (UFPA), com financiamento Conselho do Nacional de Desenvolvimento Científico e Tecnológico (CNPq). A autora agradece à professora Magda Ricci, pela orientação da pesquisa, e aos professores Aldrin Figueiredo e Silvana Rubino, pelas contribuições feitas na ocasião do Exame de Defesa. Um agradecimento mais do que especial vai para Vicente Salles (in memoriam), intelectual aqui privilegiado, que nos distinguiu com comentários sobre a primeira versão do texto.
} 


\title{
Under the Shadow of the Precursor: production and reception of the work $O$ Negro no Pará, by Vicente Salles
}

\begin{abstract}
In this paper I shall analyze the production and reception of the classical work O Negro no Pará sob o regime da Escravidão, released by Vicente Salles (1931-2013) in 1971, from the premise that understanding a polygraph intellectual as Salles can be interpreted through key (and not necessarily linear) moments of his professional path, as suggested by Pierre Bourdieu. Professional path, in this case, dedicated to studies on the black people, folklore, and popular music in Amazonia. Using Stuart Hall's theory of reception, communicative forms and discursive practices - particularly the relationship between the producer-encoder and the receivers-decoders -, I analyze a diverse set of sources such as letters exchanged by Vicente Salles with other paraense intellectuals, newspapers and interviews with the intellectual now examined.
\end{abstract}

Keywords: O Negro no Pará; Vicente Salles; Amazonia; Intellectual History; Production-Encoding; Reception-

Decoding.

\section{Introdução}

O pesquisador e folclorista paraense Vicente Salles (1931-2013), autor de diversos estudos dedicados ao negro, ao folclore e à música, é, sem dúvida, referência nos estudos sobre a cultura popular na Amazônia. Em grande medida, a sua aproximação e o seu interesse em relação a essas temáticas ocorreram por influência de intelectuais como o poeta paraense Bruno de Menezes e o antropólogo baiano Edison Carneiro, mas também pelo contato com as fontes orais e escritas arraigadas ao seu trabalho de pesquisador e folclorista (MAFRA, 2014). 
Nascido no município de Igarapé-Açu, no Pará, em 27 de novembro de 1931, Salles passou boa parte de sua infância percorrendo os diversos interiores do estado em que nasceu. No munícipio de Castanhal passou mais tempo, de 1937 a 1946 - quando se mudou em definitivo para Belém. Na capital paraense, fixou-se no bairro da Cidade Velha, onde conheceu e se tornou próximo de Bruno de Menezes, uma das personalidades influentes na vida profissional de Salles. A sua introdução no universo dos grupos populares, assim como o seu contato com os "batuques, pássaros e bois" e, igualmente, com a literatura sobre o negro, se manifestaram através da contribuição de Menezes. Foi justamente nesse contexto que Salles "começou" a se interessar pela expressão "negra" no folclore e na música popular da região amazônica. ${ }^{2}$

Em 1954, Edison Carneiro visitava a Amazônia pela primeira vez, ficando hospedado na casa de Bruno de Menezes, durante o mês de junho. Salles os acompanhou nas visitas pelos terreiros e parques de Belém, aos batuques, mercados e feiras, chegando a acompanhá-los nas exibições do "pássaro quati” no tablado, uma espécie de circo que se apresentava na Rua Humaitá, onde o público lotava as arquibancadas (SALLES, 1990). Carneiro veio à Amazônia três vezes entre os anos de 1954 e 1955, e as suas investigações e observações sobre Belém ficaram registradas em seu livro $A$ Conquista da Amazônia, em que descreveu a economia e o espaço geográfico da região, assim como a Belém da década de 1950, seu folclore, sua cultura popular, o ambiente cultural da cidade que Salles ainda vivia (CARNEIRO, 1956). ${ }^{3}$

Destas visitas e do contato pessoal entre ambos, Carneiro faria uma proposta a Vicente Salles. O desafio era proceder a um levantamento dos terreiros de cultos afrobrasileiros de Belém. ${ }^{4} \mathrm{O}$ interesse era que, a partir desta pesquisa, se pudesse comprovar

\footnotetext{
${ }^{2}$ Palestra pronunciada por Vicente Salles no Simpósio: Edison Carneiro e a Cultura Afro-brasileira, em o9 de novembro de 1988, no Salão Henrique Oswald, Escola Nacional de Música no Rio de Janeiro. Iniciativa do Centro de Letras e Artes da Escola de Música da Universidade Federal do Rio de Janeiro. Esta palestra tomou forma de microedição na década de 1990: (SALLES, 1990).

3 Cabe-nos elucidar que as visitas de Edison Carneiro à Amazônia, na década de 1950, foram realizadas a trabalho. Uma vez pela Campanha Nacional de Aperfeiçoamento de Pessoal de Nível Superior (CAPES), e outras duas vezes em missão da Superintendência do Plano de Valorização Econômica da Amazônia (SPEVEA) e do Instituto Nacional de Imigração e Colonização (INIC). Nesse período, este intelectual fez observações bem peculiares da cidade de Belém, sobre seu aspecto cultural.

${ }^{4} \mathrm{O}$ que viria a ser feito, também, pelo Professor Napoleão Figueiredo e por Anaíza Vergolino. No prefácio de O Negro no Pará, Arthur Cezar Ferreira Reis destaca que, a bibliografia sobre a presença africana na
} 
a presença e a intensidade da cultura africana negra na cidade de Belém, o que nos estudos da época representava uma zona de opacidade. Posteriormente, essa perspectiva inicial foi ampliada, indo além da compreensão dos cultos e da religiosidade afro-brasileira na Amazônia. Doravante, a discussão central seria a própria presença negra no Pará, objeto de estudo de Vicente Salles em sua especialização e que veio originar a sua mais proeminente obra, O Negro no Pará sob o regime da escravidão, publicada em 1971.

Assim, para compreendermos o local da referida obra na trajetória de Vicente Salles, partimos da análise da narrativa e da perspectiva política em O Negro no Pará, do mapeamento e interpretação da Coleção Vicente Salles, ${ }^{5}$ e do uso de uma breve narrativa biográfica escrita por nosso próprio intelectual, intitulada Um retrospecto. Publicada como microedição, podemos considerá-la enquanto uma "ferramenta fundamental" para analisarmos e cruzarmos informações a respeito de Vicente Salles e sua produção, dentre elas, a confecção da obra pioneira sobre a presença negra na Amazônia, que teve como objetivo reunir e comprovar, através de documentação, a contribuição dos africanos no meio social, cultural e econômico no extremo norte do Brasil, particularizando as lutas de classes e o aspecto culturalista.

Dentro da Coleção, chamou-nos atenção as cartas que Vicente Salles trocou com os mais diversos intelectuais, instituições e amigos, no Brasil e no exterior, e através delas buscamos observar a recepção de O Negro no Pará para os intelectuais locais, e de como foi acolhido no meio acadêmico, uma vez que Salles desenvolveu sua narrativa de forma analítica, mas bastante acessível, sem a presença de uma escrita rebuscada, o que possivelmente, tenha vindo a ser um dos motivos para o livro ter se tornado referência não somente entre historiadores profissionais, mas entre diversas áreas de conhecimento, assim como pelo público em geral.

Amazônia nunca foi expressiva e nos apresenta algumas como: O Negro na empresa colonial dos portugueses na Amazônia (1961), de sua autoria; A introdução do negro na Amazônia (1938) e Negrosescravos na Amazônia (1952), de Nunes Pereira; e os estudos dos batuques de Belém realizados por Anaíza Vergolino e Napoleão Figueiredo, divulgados nas atas do simpósio sobre a biota amazônica, no Rio de Janeiro, em 1967.

${ }^{5}$ A Coleção Vicente Salles está sob a guarda da Universidade Federal do Pará, e encontra-se no museu da mesma universidade. 


\section{Situando a produção sobre o negro na Amazônia e no Brasil}

Assim como o historiador Arthur Cezar Ferreira Reis, os antropólogos Anaíza Vergolino e Napoleão Figueiredo, em um contexto amazônico, analisariam a "ausência", na historiografia local, do negro sob um aspecto cultural, uma vez que podemos encontrar informações importantes sobre os negros nos relatos de viajantes naturalistas que na Amazônia estiveram, mesmo que esses naturalistas houvessem se silenciado quanto ao culto dos negros. Porém, a omissão maior deveria ser cobrada da historiografia clássica da Amazônia, visto que nenhum historiador "clássico" fez referência ao assunto, mostrando e reduzindo a participação do negro à economia regional (FIGUEIREDO; VERGOLINO, 1967, p. 102 e BEZERRA NETO, 2010).

Igualmente, Vicente Salles, na primeira edição de O Negro no Pará, apontava a "diminuição" com que a contribuição cultural do negro na Amazônia era tratada. Abordou sobre a literatura etnográfica, em que a cultura indígena se apresentou como o centro das atenções. ${ }^{6}$ Assim, Salles observou a ausência da presença negra em obras de folcloristas como José Veríssimo e Santa-Anna Nery. Porém, destaca a presença do negro, mestiço e mulato, em obras literárias como as de Inglês de Souza, Juvenal Tavares e Dalcídio Jurandir. Além disso, Salles complementaria a introdução sobre o tópico a respeito do negro e a composição étnica no Pará, ressaltando os nomes de pesquisadores que estavam em "evidência", no que diz respeito ao estudo do folclore africano na Amazônia, tais como: Nunes Pereira, Gentil Puget, Bruno de Menezes, Jorge Hurley e Levi Hall de Moura, assim como os antropólogos Napoleão Figueiredo e Anaíza Vergolino (SALLES, 1988, p. 67-68).

A partir das considerações feitas acima sobre o assunto, verificamos a importância de situarmos a obra de Salles no contexto da "produção" sobre o tema do negro na Amazônia - e, mais especificadamente, no Pará -, a partir da produção de historiadores e antropólogos. Em 1976, ao tratar acerca da presença africana na Amazônia, o antropólogo Napoleão Figueiredo falaria sobre alguns estudos direcionados a essa região

\footnotetext{
${ }^{6}$ Nesse sentido, poderíamos citar como exemplo o livro Santos e Visagens, de Eduardo Galvão (1976), que praticamente desconsidera a influência negra na constituição da religiosidade do caboclo amazônico, considerando-a fruto da miscigenação de portugueses e indígenas.
} 
(FIGUEIREDO, 1976, p. 145-160). Igualmente, o historiador José Maia Bezerra Neto, nos apresenta a trajetória dessa produção, tanto na Amazônia, como no Brasil, inclusive ao mencionar, o pioneirismo de Nunes Pereira (BEZERRA NETO, 2010).

O antropólogo Manuel Nunes Pereira, por exemplo, poderia ser considerado "precursor” no que se refere à introdução do negro na Amazônia; porém, devemos levar em consideração um episódio que ocorreu em Belém, em 1938, que junto a Nunes Pereira, estiveram alguns intelectuais como Bruno de Menezes, Dalcídio Jurandir, Eustachio de Azevedo, Paulo Euleutério Filho, entre outros. Em dezembro de 1938, um grupo de intelectuais liderados pelo compositor e folclorista Gentil Puget fez-se presente no Palácio do Governo para entregar ao Interventor Federal, José Carneiro da Gama Malcher, um documento no qual se solicitava a liberdade dos cultos afro-brasileiros que tinham sido proibidos pela Polícia, pois estes intelectuais defendiam que os batuques ainda tinham um caráter religioso. ${ }^{7}$ Cabe ressaltar que essas agitações da década de 1930, especialmente, a do ano de 1938, tenham se desenvolvido, também, por conta dos 50 anos da abolição da escravidão.

Outros acontecimentos devem ser rememorados nas primeiras décadas do século XX em Belém. Antes de ocorrer o movimento pela liberdade de culto em 1938, houve a visita de Mário de Andrade a Belém, na década de 1920, e posteriormente, a visita da Missão Folclórica Paulista, na década de 1930. Acreditamos que seja pertinente nos lembrarmos novamente desses fatos e, dessa forma, relacioná-los com os manifestos ocorridos em Belém, nesses anos iniciais, uma vez que existia um movimento cultural nacional que queria penetrar e conhecer a essência cultural do País e suas

\footnotetext{
7 Ver O Negro no Pará, em que Salles trata o assunto de forma mais apurada. Cf., também, A Modinha no Grão Pará, em que o autor fala sobre Gentil Puget. Nunes Pereira, embora maranhense, sempre esteve muito ligado às pesquisas no Pará. Em uma das cartas presentes na Coleção Vicente Salles, Napoleão Figueiredo comenta sobre a passagem de Nunes Pereira por Belém, tendo de regressar ao Maranhão, onde estava desenvolvendo uma pesquisa no interior. Museu da UFPA (MUFPA). Coleção Vicente Salles (CVS). Carta de Napoleão Figueiredo a Vicente Salles - Belém, 10/06/1970. Temos notícias que o texto de Nunes Pereira, A Introdução do Negro na Amazônia, foi publicado no Boletim Geográfico do Rio, em 1949. Embora, Ferreira Reis direcione o ano de 1938 na apresentação de $O$ Negro no Pará, acreditamos que este texto, possivelmente, tenha sido publicado anteriormente de forma fragmentada no Jornal "A Folha do Norte".
} 
particularidades. ${ }^{8}$ É provável que essas visitas possam ter sido tomadas com um “incentivo" para a luta pela liberdade de culto dos negros em Belém.

Do mesmo modo, devemos levar em consideração os acontecimentos da década de 1930, uma vez que refletem diretamente na produção e discussão sobre os trabalhos que foram confeccionados antes e ao tempo da obra de Salles, pois muitas das personalidades que participaram do movimento destacado foram responsáveis por demonstrar o espaço que o negro conquistou, por exemplo, em meio ao quadro urbano de Belém. Nesse período, intelectuais, pintores, músicos e artistas já andavam em sintonia com essa discussão, a exemplo da Exposição de Belas Artes, ocorrida em 1938, em Belém, comemorativa ao cinquentenário da abolição dos escravos no Brasil, que soou mais com caráter de manifestação.

Nesse sentido, acreditamos que a exposição em questão expressou bem o interesse desses intelectuais. Realizada no sugestivo dia 13 de maio, em Belém, a exposição de Belas Artes de 1938 não teve, por assim dizer, um caráter “oficial”, mas se apresentou de forma ímpar, uma vez que não se limitou a exposições de obras visuais, sendo extensiva à forma escrita, através de poemas e de outros textos que expressaram o sofrimento da escravidão e a representatividade da cultura afro no costume amazônico. Assim, acreditamos que seja pertinente rememorarmos essas manifestações da década de 1930 em Belém, pois essas reflexões fizeram parte dos ideais daqueles intelectuais que participaram desse contexto, e consequentemente, incentivando inúmeros estudos sobre o tema no espaço amazônico.

No intento de obtermos uma descrição mais detalhada sobre a produção historiográfica brasileira a respeito da escravidão, podemos apontar o trabalho do historiador Stuart Schwartz em Escravos, roceiros e rebeldes, em que o autor, inicialmente, procura propiciar ao leitor o contato com a produção recente sobre tal assunto. No entanto, Schwartz procura esclarecer que seu objetivo está em apresentar uma descrição

\footnotetext{
${ }^{8}$ Sobre a questão de desvendar as particularidades culturais do Brasil, pelos intelectuais do início do século $\mathrm{XX}$, é importante atentarmos à preocupação em desvendar o folclore africano na Amazônia uma vez que, nesse período, esse assunto atraía atenção tanto local, como nacional. Figueiredo destaca a recepção do livro de Edison Carneiro: Religiões Negras, em 1938, pela Guajarina, por exemplo. Cf. (FIGUEIREDO, 2008, p. 227-228).
} 
e uma análise das tendências na historiografia, e não uma listagem que contenha os autores e suas publicações sobre o assunto. Assim, o autor inicia suas análises a partir do clássico Casa-Grande e Senzala, de Gilberto Freyre, de 1933, apontando que, foi depois desse livro que, de fato, a escravidão e os africanos ganharam destaque na história do Brasil, embora, a partir da concepção da ideia de "democracia racial” (SCHWARTZ, 2001, p. 22).

Segundo Schwartz, na década de 1950, os acadêmicos brasileiros se lançaram em um "rumo revisionista", reagindo, dessa forma, às dinâmicas intelectuais e sociopolíticas de dada realidade; dessa forma, o autor ressalta que as críticas feitas a Gilberto Freyre, no Brasil, nas décadas de 1950 e 1960, vinham de “jovens sociólogos” de São Paulo influenciados pelo marxismo e pela percepção materialista da sociedade. Estes intelectuais estavam mais preocupados em analisar o sistema escravista no desenvolvimento da economia brasileira, geralmente a partir da perspectiva das relações raciais. Nesse sentido, o autor procura demonstrar o rumo que esses trabalhos acadêmicos tomaram nas décadas de 1950 e 1960 (SCHWARTZ, 2001, p. 26). ${ }^{9}$

Dessa forma, nas décadas seguintes (1970 e 1980), o autor nos situa sobre o direcionamento desses estudos na historiografia brasileira, destacando que, nesse período, os métodos quantitativos passaram a ser bastante utilizados - como ainda o são - pelos estudiosos do escravismo e da escravidão sobretudo, nos trabalhos que buscam integrar ambas as perspectivas. Nesses termos, a nova historiografia da escravidão compreende a forma de trabalho e seu aspecto social e cultural (SCHWARTZ, 2001, p. 2829). É nesse contexto que a obra de Salles se enquadra, pois, em O Negro no Pará, o autor apresenta uma análise, na qual examina ambas as perspectivas: assim como Salles se utilizou dos recenseamentos antigos, foram também utilizadas as anotações de cronistas, que registraram os costumes dos negros na Amazônia. ${ }^{10}$

\footnotetext{
9 Os intelectuais da escola paulista de sociologia concentraram-se, principalmente nos estudos sobre o escravismo no sul do Brasil e no século XIX. Estes trabalhos contribuíram, principalmente, para os estudos comparativos da escravidão, e segundo o autor, intensificou-se o interesse pelo estudo da escravidão no Brasil.

${ }^{10}$ É importante salientar as formas que tomavam os estudos sobre o negro no Brasil ao longo das décadas mencionadas, uma vez que a "nova historiografia" permite que se compreenda a escravidão (seu sistema e funcionamento) como forma de trabalho, e enquanto sistema social e cultural, no sentido de
} 
De modo geral, Vicente Salles estabelece um código de linguagem que, em certa medida, corrobora com a "desnaturalização" de uma leitura que por longo tempo foi estabelecida sobre a formação econômica, social e cultural da Amazônia, que privilegiava os portugueses e, sobretudo, os indígenas em detrimento dos africanos. Logo, não seria de todo irreal supormos que a obra de Salles tenha se tornado, a partir da década de 1970, responsável por "naturalizar" uma nova ideia: a de que a presença africana na formação histórica da Amazônia foi determinante, ainda que em termos distintos daqueles em que se estabeleceram para outras regiões do Brasil. ${ }^{11}$

\section{Considerações sobre as edições da obra O Negro no Pará sob o regime da escravidão}

Escrito na década de 1960, época em que trabalhava com Edison Carneiro e finalizava sua especialização em Antropologia na Faculdade Nacional de Filosofia da Universidade do Brasil, a primeira edição de O Negro no Pará seria publicada somente em 1971. O período de produção e publicação do livro de Salles se deu em um momento bastante conturbado na história do Brasil com o regime militar, uma vez que os valores democráticos foram derrotados em 1964 (REIS, 2000). Em Um retrospecto, Salles aborda sobre a militância do amigo Edison Carneiro destacando que, a Campanha de Defesa do Folclore Brasileiro foi visitada algumas vezes por Luís Carlos Prestes. ${ }^{12}$ O grupo “esquerdista” que Salles frequentava deveria dificultar a publicação de sua obra sobre o negro. Contudo, mesmo no período da ditadura militar, as edições poderiam ser publicadas por outros mecanismos.

alargar a compreensão da história do Brasil e de sua economia. A análise, a partir dessa perspectiva não foi muito bem aceita por alguns intelectuais como Jacob Gorender, por exemplo.

11 Procuramos posicionar a obra de Salles a partir das ideias de "naturalização" e "desnaturalização" problematizadas por Stuart Hall, e sobre a produção de reconhecimentos "aparentemente naturais", a partir da operacionalização dos códigos (conjunto de signos que possibilitam a construção e transmissão das mensagens). Embora este autor direcione suas discussões para práticas discursivas de uma mídia televisiva, consideramos pertinente realizar tal conexão (Cf.: HALL, 2003, p. 393).

${ }^{12}$ Em sua memória autobiográfica, Salles faz um breve apanhado sobre alguns acontecimentos nesse período conturbado da história do Brasil, como, por exemplo, a sua reação no dia seguinte ao golpe militar de 1964, ao chegar ao seu local de trabalho no Rio de Janeiro, e a utilização de algumas estratégias para burlar as perseguições (SALLES, 2007, p. 19). Foi neste ambiente que Vicente Salles conviveu com um grupo intelectual de esquerda, que tinha figuras como: Astrogildo Pereira, Eneida de Moraes, Dalcídio Jurandir, Heloísa Ramos (OLIVETO, 2007, p. 25). 
Sucintamente, Salles, em uma entrevista ao Jornal de Brasília, abordou o contexto de produção e dedicação à obra em questão. Nesse sentido, o folclorista esclarece que o trabalho realizado sobre o levantamento da participação do negro na história amazônica foi iniciado ainda em Belém, por volta de 1952, estendendo-se por mais de dez anos. Salles destaca, inclusive, que o projeto de tese foi diluído em 1964, tendo O Negro no Pará sob o regime da escravidão sido refeito e publicado somente em $1971 .{ }^{13}$ Produto do diálogo com uma densa documentação, Salles percorreu instituições de pesquisa como o Arquivo Público do Pará, Arquivo Nacional, Instituto Histórico e Geográfico Brasileiro e Biblioteca Nacional.

Este folclorista descreveu, em uma de suas cartas presentes na coleção, o que é fazer pesquisa por conta própria e sem “incentivo". Além disso, o autor apontou na apresentação da primeira edição do livro que a obra "também pretende ser uma interpretação", a partir da bibliografia que considerou importante e disponível à época, assim como os documentos coletados, entre os quais estão: relatórios, jornais, revistas, sensos, entre outros.

Vicente Salles fez questão de destacar a importância do político e historiador Arthur Cezar Ferreira Reis para a publicação da primeira edição de O Negro no Pará. ${ }^{14}$ Nesses termos, seria praticamente impossível não refletirmos a respeito de como Salles conseguiu burlar sua narrativa carregada pela ideologia marxista nesta obra, uma vez que, conseguindo publicar um livro imbuído de passagens que demonstraram o sentido ideológico, da politização dos negros em meio à luta cabana que ocorreu no norte do Brasil, não chamou a atenção da vigilância que se estabeleceu no País. Ferreira Reis era um intelectual conservador, que estava ligado à nova ordem estabelecida em 1964, mas apoiava o desenvolvimento cultural do País, especialmente o da Amazônia (BURNS, 1967, p. 111-116). É possível que por conta disso, Ferreira Reis tenha “deixado passar” a postura

\footnotetext{
13 Entrevista: "De uma Amazônia lúdica, o lixo revelador da Antropologia" / por Claver Filho. Museu da UFPA (MUFPA). Coleção Vicente Salles (CVS). Jornal de Brasília. Brasília, 21 de agosto de 1982.

${ }^{14}$ Podemos perceber o destaque que Salles direciona a Ferreira Reis, tanto na apresentação da $2^{\text {a }}$ edição de O Negro no Pará, como no documentário sobre o livro, no sentido de ter acreditado e apadrinhado o livro. Ele foi o responsável por negociar a publicação com a Universidade Federal do Pará para a primeira edição. Cabe ressaltar que, a primeira edição de O Negro no Pará foi coeditada pela Universidade Federal do Pará com a Fundação Getúlio Vargas, em 1971.
} 
marxista de Salles, e foi o principal intermediário da publicação em convênio com a Fundação Getúlio Vargas e a UFPA. ${ }^{15}$

Nesse contexto, Ferreira Reis se apresentava como um historiador que mantinha um bom relacionamento com o regime militar instaurado e, como presidente do Conselho Federal de Cultura, intermediou a reedição de Motins Políticos, de Domingos Antônio Raiol ${ }^{16}$, em 1970 - reeditado pela Universidade Federal do Pará (LIMA, 2010, p. 72-103) -, e "apadrinhou" no ano posterior O Negro no Pará sob o regime da escravidão, de Vicente Salles. É importante situarmos que, à altura da confecção e publicação desse último, deuse o golpe civil-militar e governaram nesse ínterim Castelo Branco, posteriormente Costa e Silva e, em 1969, assumiria o general Garrastazu Médici, considerado um dos governos mais repressivos do período militar.

Foi em um cenário de violência, repressão e intolerância com as pessoas que contestavam o governo militar que se estabelecia e se fortalecia a cada dia, que o livro foi produzido; desse modo, não poderíamos deixar de destacar os aspectos mencionados. $O$ exílio foi um, entre tantos exemplos de punição para os subversivos. Como demonstra a historiadora Denise Rollemberg (2004, p. 285) em seu texto Nômades, sedentários e metamorfoses: trajetórias de vidas no exílio, Salles não chegaria a ser punido com ferocidade após o golpe, mas se viu implicado em alguns inquéritos, embora não tenha se envolvido em maiores complicações "pela pouca militância partidária”, como o próprio salientou (SALLES, 2007, p. 20-21). Sua militância, também, se deu no movimento estudantil, pois era universitário na época do golpe civil-militar.

Permanecendo, no que tange aos reflexos da primeira edição de O Negro no Pará, no contexto de um regime ditatorial, faz-se relevante abordar sobre os centro e organizações negras no Brasil, para compreendermos melhor a ligação entre esses movimentos e a obra em questão. Como consequência dos atos repressivos dos governos militares, muitas organizações negras tiveram que se camuflar através de entidades

\footnotetext{
${ }^{15}$ Entrevista concedida à autora, através de e-mail, em março de 2012.

16 Domingos Antônio Raiol foi um historiador e político paraense que também fez parte de uma geração de intelectuais no Norte do Brasil na metade do século XIX. Escreveu Motins Políticos ou história dos principais acontecimentos políticos na Província do Pará desde o ano de 1821 até 1835, obra em que tratou sobre a história política e social do Norte do Brasil, mas, além disso, compartilhou com os propósitos políticos e ideológicos do Regime Monárquico. Cf.: LIMA 2010.
} 
culturais e de lazer. Segundo Albuquerque e Fraga Filho (2006), no final da década de 1960, por exemplo, um grupo de intelectuais fundou o Centro de Cultura e Arte Negra, no bairro do Bixiga, em São Paulo (ALBUQUERQUE; FRAGA FILHO, 2006, p. 281), demonstrando, dessa forma, que essas organizações não se deixaram intimidar pela repressão da ditadura instalada no Brasil.

Dialogando com um contexto amazônico, a antropóloga Anaíza Vergolino, em sua dissertação sobre a Federação Espírita Umbandista e dos Cultos Afro do Pará (VERGOLINO, 1976), salientou que, até o ano de 1964, em Belém, existia um grande número de casas de culto que funcionavam sob licenças especiais outorgadas pela Polícia, em virtude das "agitações" que envolviam esses estabelecimentos. Sobre o governo militar que se instalou no Pará em 1964, a autora destaca que este, considerava os batuques como ato de desordem, dessa forma, estabeleceu-se uma "guerra" contra os terreiros, uma vez que, as licenças ficariam cada vez mais difíceis de serem obtidas, daí o surgimento da proposta da criação de uma “Federação". Nesses termos, compreendemos os esforços para o não fechamento das casas de cultos em Belém, possivelmente, a partir de certas "estratégias".

Ao passarmos para a década seguinte (1970), verificamos a preocupação em mostrar a importância do negro na história do Brasil; principalmente no aspecto cultural, a década de 1980 seria uma extensão, caracterizada pela criação de diversas organizações negras e comissões para a formulação de políticas de inclusão dos negros na sociedade (ALBUQUERQUE; FRAGA FILHO, 2006, p. 290). ${ }^{17}$ Igualmente, percebemos 0 fortalecimento desses movimentos sociais ao longo da produção e das publicações do livro de Vicente Salles. Nesse sentido, seria importante ressaltarmos essa ligação da obra de Salles entre grupos e entidades de movimentos negros no Brasil e a ligação que se

\footnotetext{
${ }^{17}$ Entre outras considerações, os autores destacam a década de 1970 como o período em que os militantes negros passaram a dar forma às articulações de suas ações numa entidade nacional. O Movimento Negro Unificado, por exemplo, contestava a ideia que se vivia em uma democracia racial, ideia compartilhada pelos militares. Igualmente, a questão racial não tinha espaço nas organizações de esquerda, que encaravam a questão do preconceito e da desigualdade como processo de exploração da sociedade capitalista.
} 
estabeleceu com o livro ${ }^{18}$, uma vez que, após a publicação da obra, muitos grupos passaram a debater o assunto de forma intensa. ${ }^{19}$

No Pará, o livro interessou diretamente ao Centro de Estudos e Defesa do Negro no Pará - CEDENPA, tendo a oportunidade de discuti-lo diretamente com o autor. Posteriormente, em pleno momento do centenário da abolição da escravidão no Brasil, esse centro contribuiu para a tiragem da segunda edição em $1988 .{ }^{20} \mathrm{O}$ momento do centenário foi marcado pelo "calor" das discussões sobre a identidade racial e sobre a marginalização do negro no Brasil. No que se refere a Belém, podemos destacar, por exemplo, a notícia sobre a "Semana de História" ocorrida na Universidade Federal do Pará, em maio de 1988, com o tema Centenário da Abolição: o negro na formação da sociedade brasileira, evento para qual Vicente Salles foi convidado a participar. O objetivo do evento foi o de apresentar discussões sobre as diversas visões do racismo na área da História, Sociologia, Filosofia e Antropologia. ${ }^{21}$

Nesse contexto, deu-se o relançamento da obra, agora em sua segunda edição, exatamente no dia $1^{\circ}$ de dezembro de 1988, com o seguinte título: Vicente Salles relança seu livro mais vendido. Segundo a matéria, Vicente Salles apontou que esta edição foi um fac-símile da primeira edição, e que apresentou como acréscimo, somente, uma nota explicativa sobre a reedição da obra, ressaltando que, a segunda edição foi editada com verbas do Ministério da Cultura, atendendo a indicação feita pelo CEDENPA. Salles reafirmou a grande repercussão do livro em 1971, principalmente, pela obra ter sido considerada um documento concreto, no qual se comprova que existiu, de modo efetivo, a escravidão negra no Pará. Na mesma entrevista, assegurou sobre a tentativa dos

\footnotetext{
18 O comentário sobre essa repercussão está presente na apresentação da segunda edição de O Negro no Pará.

19 Sobrea ligação desses movimentos e "afinidade" com a obra, seria pertinente dialogarmos com alguns posicionamentos apresentados por Chartier e Bourdieu, no que diz respeito às "práticas de leitura". Cf. (CHARTIER, 1996). Bourdieu, por exemplo, aponta que, entre os fatores que predispõem alguém a ler alguma coisa ou a ser influenciado, é preciso que se reconheçam as afinidades entre as disposições do autor e do leitor (inclinação). É interessante, também, chamarmos atenção para algo que ele destacou como "revolução dos costumes", no sentido de se constituir um efeito simbólico sobre algo que não poderia ser publicado.

20 A segunda edição de O Negro no Pará fez parte de um programa realizado em comemoração ao centenário da abolição da escravatura no Brasil e de um convênio entre o Ministério da Cultura, Secretaria de Cultura do Pará e da Fundação Cultural do Pará.

${ }^{21}$ Museu da UFPA (MUFPA). Coleção Vicente Salles (CVS). O Liberal. Belém, 03 a 10 de maio de 1988.
} 
brancos em escravizar os índios no Pará que resultou em um verdadeiro genocídio, pois inúmeras tribos não se submeteram à escravidão, razão pela qual houve a necessidade de recorrer à mão de obra escrava. ${ }^{22}$

Em 2005, a terceira edição de O Negro no Pará sob o regime da escravidão foi editado pelo Instituto de Artes do Pará - IAP, através do Programa Raízes ${ }^{23}$. Em nota à terceira edição, Salles destaca que o texto que constitui o livro foi revisto e ampliado e que contém acréscimos de notas e documentos, contudo, esse procedimento não foi realizado de forma profunda. Esta terceira edição demonstra como a pesquisa sobre a presença negra na Amazônia se ampliou constantemente, pois Salles já teria destacado, desde a primeira edição, sobre as possibilidades de alargamento do estudo acerca do tema do negro na Amazônia e deixou para fazer os acréscimos em dois livros complementares: O Negro na Formação da Sociedade Paraense e Vocabulário Crioulo.

Ainda sobre esta terceira edição, seria pertinente destacarmos algumas observações. Ao resenhar a obra em questão, Bezerra Neto (2008) aponta interessantes considerações sobre as edições anteriores, entre outros aspectos, salientando a necessidade dessa publicação após dezessete anos da segunda edição. Estabelecendo uma breve comparação entre as publicações, o autor destaca ser perceptível o "cuidado" editorial e gráfico que foi dispensado a esta terceira edição, que viria a ser editada na condição de clássico da historiografia brasileira.

A partir da publicação desta terceira edição foi produzido um documentário sobre o processo de pesquisa do livro de Salles intitulado O Negro no Pará: cinco décadas depois, uma vez que foram levadas em consideração as pesquisas iniciadas na década de 1950. Este documentário foi constituído por alguns depoimentos, como o da antropóloga Anaíza Vergolino e de integrantes do movimento negro no Brasil, assim como, do próprio Vicente Salles falando das pesquisas para o livro e sua contextualização.

\footnotetext{
${ }^{22}$ Museu da UFPA (MUFPA). Coleção Vicente Salles (CVS). O Liberal. Belém, 01 de dezembro de 1988.

23 Programa Raízes foi criado pelo Governo do Estado do Pará através da lei 4.054, tendo como missão articular no âmbito do governo estadual o atendimento aos povos indígenas, e às comunidades quilombolas, recebendo suas reivindicações, avaliando-as, para posteriormente encaminhá-las ao órgão competente. Entre outros projetos, está o de valorização da cultura dos quilombolas. Disponível em: <http://www.cpisp.org.br/htm/leis/pao6.htm> (Acesso em: 20 abr. 2012).
} 
Seria válido atentarmos para as capas que caracterizaram as edições de O Negro no Pará, após falarmos sobre o contexto da produção, publicação e reedição deste livro. A capa da primeira edição dessa obra se apresenta de forma neutra, fazendo alusão à Amazônia, a partir do desenho das vitórias régias, e foi a capa padrão da Coleção Amazônica, editada pela UFPA. A segunda edição veio a apresentar uma capa mais "forte", a cor preta em predominância à branca, e ora essas cores se "misturando", a partir da cor "chave”. Por fim, temos a terceira edição, na qual o cabelo afro aparece em sua essência, dominando a capa do livro. Ao que parece, as capas representam "seus momentos", a fase de discrição e posteriormente de afirmação daquilo que se tratava.

Capa da $1^{\mathrm{a}}$ edição de O Negro no Pará (1971)

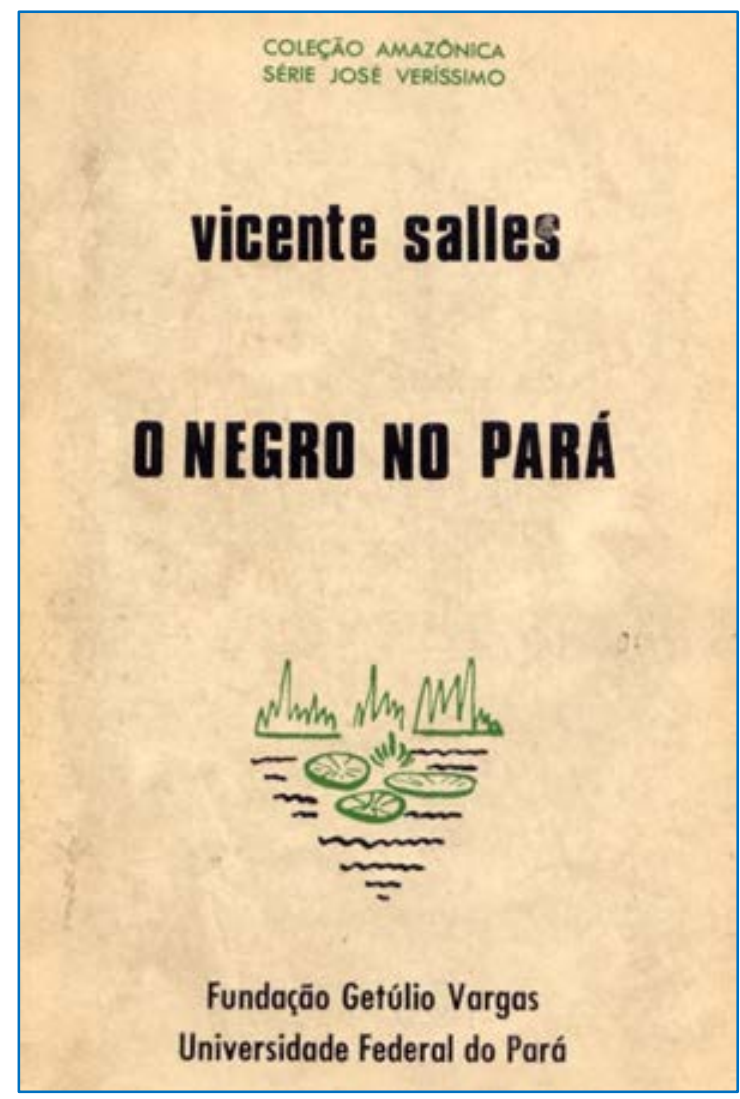

Fonte: arquivo pessoal de Vicente Salles
Capa da $2^{\mathrm{a}}$ edição de O Negro no Pará (1988)

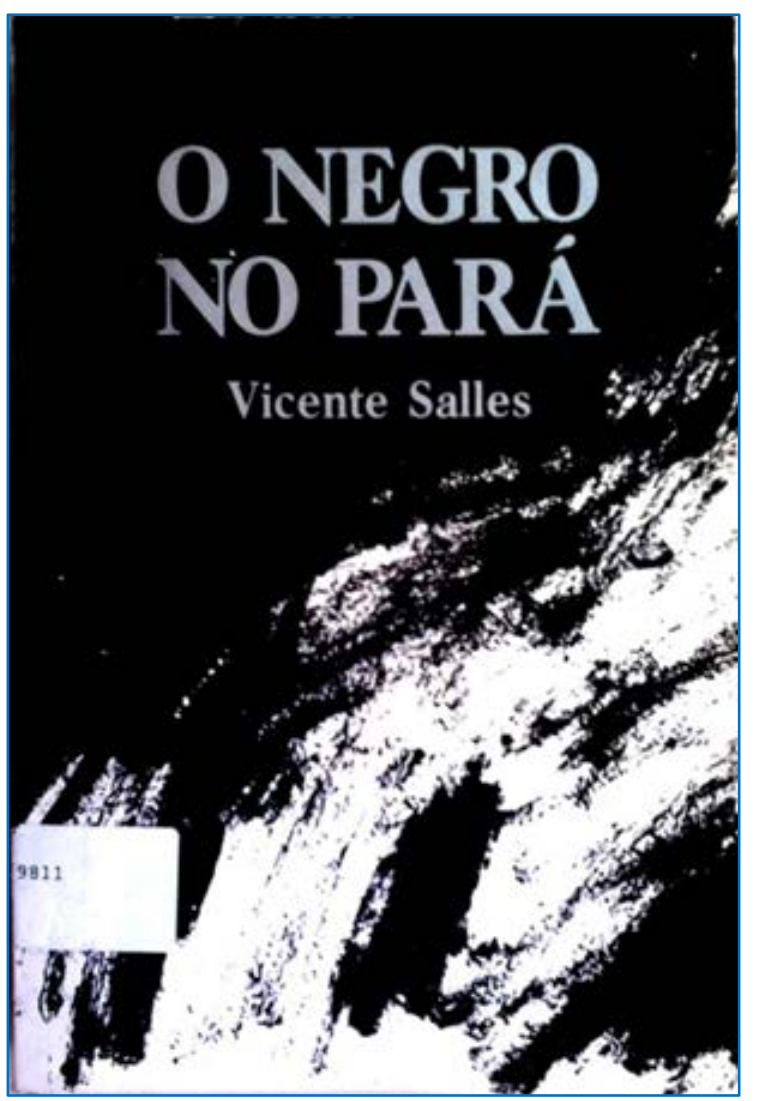

Fonte: arquivo pessoal de Vicente Salles 


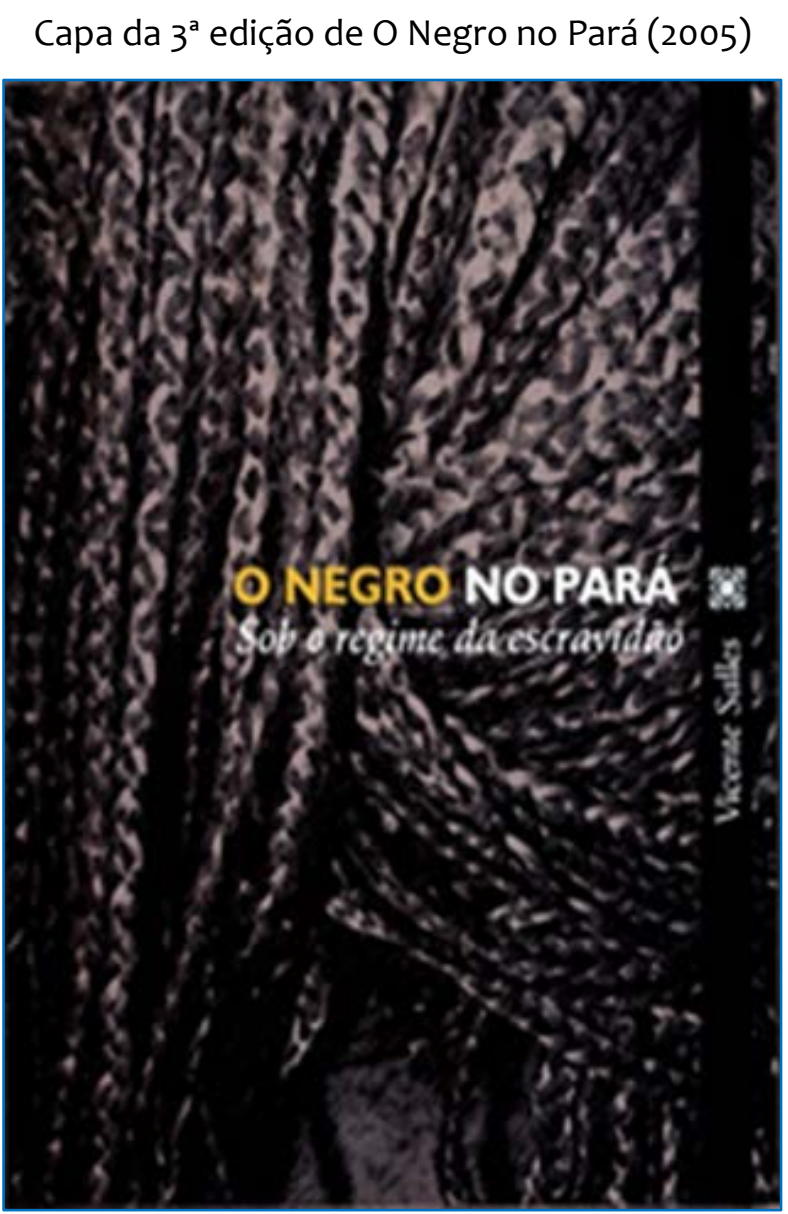

Fonte: arquivo pessoal de Vicente Salles

Como mencionamos anteriormente, o livro em questão teve o objetivo de comprovar a contribuição dos africanos no meio social, cultural e econômico no Brasil, especificamente no Pará, que junto ao engajamento político de Salles, expresso em suas páginas, acabou por conquistar um efeito simbólico na luta de movimentos e centros de defesa do negro na região Norte. Cabe-nos ressaltar que Salles desenvolveu uma narrativa de forma analítica acessível, o que talvez explique a boa circulação de sua obra não somente entre historiadores profissionais, mas também entre diversas áreas do conhecimento.

Partindo do princípio de que Salles apresentou uma nova leitura sobre a história do Pará; das mensagens políticas retratadas em seu livro através das formas de luta e resistência; de pensar cultura popular e o folclore como mecanismos de análise social e de denúncia histórica, torna-se pertinente aproximarmos essas características às formas 
comunicativas problematizadas por Stuart Hall, de como a produção do discurso produzido por Salles foi assimilada por esse público. Uma vez que as mensagens a serem passadas para um determinado público podem vir a ter várias interpretações, justamente pelo fato de que a "mensagem" possui uma estrutura de significados bastante complexa, e que, consequentemente, não possui um caráter fixo (HALL, 2003, p. 354).

\section{Um diálogo entre Vicente Salles e seus leitores: a recepção da obra O Negro no Pará sob a ótica das correspondências}

As pesquisas de Vicente Salles sobre a participação do negro, inicialmente no contexto da Cabanagem, tomaram forma de texto no ano de 1968. Nesse ano foi publicado o texto A cabanagem, os escravos, os engenhos, na Revista Brasil Açucareiro. Este texto trataria da concentração de escravos negros na Amazônia, da participação ativa desses escravos na Cabanagem, e, principalmente, falaria sobre a vida dos negros nos engenhos. Acreditamos que este seja o primeiro trabalho publicado de Salles sobre o tema, uma vez que Salles faz menção a um trabalho seu sobre o negro na época da Cabanagem em uma carta direcionada ao antropólogo Napoleão Figueiredo, em 1968. ${ }^{24}$ Posteriormente, intensificou o assunto em O Negro no Pará.

O reflexo dos trabalhos mencionados anteriormente faz parte do livro Memorial da Cabanagem (1992), que apresenta-se em forma de um libelo político e está estruturado em dois momentos. No primeiro, o autor examina a revolução cabana de 1835, seu conteúdo ideológico e seus efeitos; no segundo momento, ele aborda o desdobramento das consequências da revolução cabana, destacando a continuidade das ideias socialistas gestadas no movimento cabano. A partir dessa breve apresentação, consideramos a relevância da obra, no sentido do autor ter dispensado atenção ao tema da participação do negro na Cabanagem - como uma extensão do que se propôs em O Negro no Pará.

Faz-se necessário observar a recepção da obra de Salles no contexto nacional, após a publicação da primeira edição de O Negro do Pará, em 1971. Quando de sua publicação inicial, a obra foi bem recebida não apenas no contexto local, como também

\footnotetext{
${ }^{24}$ Museu da UFPA (MUFPA). Coleção Vicente Salles (CVS). Carta de Vicente Salles a Napoleão Figueiredo Rio de Janeiro, 08/07/1968.
} 
em outras regiões do Brasil. Exemplo disso foi a boa acolhida pela crítica bibliográfica de Luiz Mott (1973), em que o autor classifica O Negro no Pará como obra básica, exemplo de trabalho sério e bem documentado. Além disso, a obra em questão foi citada no livro de Ciro Flamarion Cardoso Economia e Sociedade em áreas coloniais periféricas: Guiana Francesa e Pará (1750-1817), no ano de 1984. Igualmente, a mesma foi também referida por Stuart Schwartz, em seu livro Escravos, roceiros e rebeldes, em um balanço historiográfico sobre os estudos da escravidão no Brasil. Assim, como podemos perceber, trata-se de um estudo considerado importante para a compreensão da economia, da sociedade e da cultura da região norte, dentro de um contexto nacional. ${ }^{25}$

Dentro de uma perspectiva política, torna-se oportuno, para este instante, retomarmos os momentos em que o livro foi publicado e mesmo reeditado, antes de passarmos à análise mais detida sobre a recepção da obra no âmbito local, a partir das correspondências trocadas com os pares de Vicente Salles. Em suma, podemos afirmar que a primeira edição (1971) atendeu um público mais acadêmico, na medida em que se apresenta uma linguagem acessível, porém direcionada para um público instruído, uma vez que foi editado pela UFPA em convênio com FGV; a segunda edição (1988), além de contemplar as discussões acadêmicas, atende às discussões de centros e organizações em defesa do Negro; e finalmente, a terceira edição (2005), que traz a ciência de “clássico" por parte do autor.

Assim, a partir das considerações apontadas acima sobre a recepção das publicações da obra em questão, podemos entender que a assimilação da "mensagem" por parte de seus receptores, partindo da compreensão do conjunto dos seus significados, é o que "molda o ponto final da recepção", e que poderá ser utilizada de forma prática ou ideológica para o uso social ou político de uma pessoa ou de um grupo (HALL, 2003, p. 390-391). E foi o que O Negro no Pará se tornou, uma obra de referência

\footnotetext{
${ }^{25}$ É importante considerarmos o período das publicações mencionadas. Dessa forma, temos o texto de Mott (1973); o de Cardoso (1984), e o de Schwartz (2001). Sendo que este último teve o texto: A historiografia recente da escravidão brasileira, publicado em uma versão anterior, em 1988. Logo, estes autores utilizaram a primeira edição de O Negro no Pará, confirmada em suas referências bibliográficas.
} 
por representar um caráter de renovação na academia, de resistência e também de militância. ${ }^{26}$

Após falarmos brevemente a respeito da importância da obra de Salles e da sua contribuição para o estudo da escravidão brasileira, assim como de considerações mais gerais sobre a produção e recepção do seu livro, buscaremos trabalhar com as correspondências expedidas e recebidas, presentes na Coleção Vicente Salles, localizada na biblioteca do Museu da Universidade Federal do Pará, com o objetivo de percebermos a recepção da obra em questão a partir da análise do conteúdo das cartas, especialmente, através das cartas que Vicente Salles trocou com o antropólogo e professor Arthur Napoleão Figueiredo ${ }^{27}$, a antropóloga Anaíza Vergolino ${ }^{28}$ e o jornalista Lúcio Flávio Pinto. ${ }^{29}$

Na perspectiva de trabalho com um acervo pessoal e de suas possibilidades, a historiadora Ângela de Castro Gomes, em seu texto Escrita de si, escrita da história: a título de prólogo (2004), aborda a explosão de publicações de caráter biográfico e autobiográfico nos últimos dez anos e, assim, destaca o surgimento de um maior interesse dos leitores nos últimos tempos por determinado gênero de escrita, como: diários, biografias, correspondências, apontando uma maior atenção pelo indivíduo. ${ }^{30}$

\footnotetext{
${ }^{26}$ Para essa reflexão nos baseamos nas ideias problematizadas por Stuart Hall, principalmente em seu texto "Codificação e Decodificação", publicado originalmente em 1980. Essencialmente, quando o autor fala dos "circuitos de sentidos", da produção, circulação e recepção, em que a análise desse circuito gira em torno da compreensão entre produção e consumo (HALL, 2003, p. 359). Para Hall, a codificação (produção do discurso) e decodificação (recepção/assimilação) são duas práticas diferentes, mas relacionadas entre si, em que as diferenças devem ser identificadas para saber como são articuladas (HALL, 2003, p. 360).
}

${ }^{27}$ Arthur Napoleão Figueiredo é considerado uma das maiores referências no que diz respeito aos estudos antropológicos na Amazônia. Este antropólogo assumiu a cadeira de Etnologia e Etnografia do Brasil na Faculdade de Filosofia da Universidade Federal do Pará, a partir de 1960. Sua trajetória profissional foi marcada pelo pioneirismo da pesquisa de campo, tendo atuado como pesquisador e professor orientador. Este intelectual faleceu em 1989, para mais detalhes Cf.: (MAUÉS, 1999, p. 25-54 e DIAS, 2009, p. 735-761).

${ }^{28}$ Notícias sobre a trajetória docente e de pesquisa da antropóloga Anaíza Vergolino cf.: (DIAS, 2009, p. 743745).

${ }^{29}$ Lúcio Flávio Pinto é um jornalista e sociólogo, redator do Jornal Pessoal - quinzenário individual - que circula em Belém desde 1987. Foi professor do curso de jornalismo da Universidade Federal do Pará e correspondente do Jornal O Estado de São Paulo. Nasceu em Santarém (PA), no dia 23 de setembro de 1949. É autor de vários títulos sobre a Amazônia e ganhador de prêmios internacionais. Disponível em: <www.lucioflaviopinto.com.br> Acesso em: 28 fev. 2011.

${ }^{30}$ Neste texto, a autora aborda os trabalhos que vêm sendo desenvolvidos a partir das correspondências e 
Assim, devemos levar em consideração, principalmente, o olhar sobre essas correspondências, pois, a troca de cartas deve ser percebida como um espaço em que as ideias são reveladas, entre outros interesses (GOMES, 2004, p. 51-52). Nesses termos, ao trabalharmos as correspondências como fonte, estas devem sempre ser comparadas com outras fontes, no intuito de buscarmos alargar as considerações sobre o intelectual em questão, neste caso, Vicente Salles (MALATIAN, 2009, p. 195-221). O próprio Salles faz algumas considerações sobre este tipo de fonte, ao ressaltar que se trata de um “documento primoroso", uma vez que as cartas revelam facetas muito pessoais de quem as escreve. ${ }^{31}$

Cabe destacar que Vicente Salles foi um intelectual polígrafo, que mesmo distante de sua terra natal - a qual deixou ainda muito jovem - manteve intenso contato com a imprensa paraense, assim como com os intelectuais paraenses. Neste caso, poderíamos citar alguns nomes como: Lúcio Flávio Pinto, Arthur Napoleão Figueiredo, Waldemar Henrique, Anaíza Vergolino, Wilson Fonseca, entre outros, que estão entre os correspondentes de Salles, presentes em sua coleção.

\section{Muito em comum? Diálogos entre arthur Napoleão Figueiredo e Vicente Salles}

O professor Arthur Napoleão Figueiredo está entre os intelectuais que mantiveram um considerável contato através de cartas com Vicente Salles. Professor da Universidade Federal do Pará, este antropólogo veio a assumir a cadeira de Etnologia e Etnografia do Brasil nesta instituição em 1960. Com relação às correspondências existentes na coleção, temos notícias das trocas de cartas suas com Salles desde 1968 até 1988, um ano antes de seu falecimento.

As considerações que serão feitas a seguir, partem da percepção da recepção de 0 Negro no Pará sob o regime da escravidão por intermédio da correspondência trocada com

de outros tipos de documentos que comumente constituem um acervo pessoal, assim como a utilização destes como fontes ou objetos históricos. Em texto anterior, a autora já falaria do "boom" dos arquivos privados, das possibilidades e dos encantamentos para os quais este tipo de acervo pode encaminhar o pesquisador, assim como, da revalorização do indivíduo na história, da lógica de suas ações, trabalhando com os conceitos da nova história cultural, nesses termos, Cf. (GOMES, 1998, p. 121-127).

${ }^{31}$ Entrevista concedida à autora, em 30/11/2011. 
Napoleão Figueiredo. Procuraremos apresentar através destas correspondências o tipo de diálogo que estes intelectuais travavam, na época em que a obra de Salles já tinha sido finalizada, e perceber como foi sua aceitação no meio acadêmico após a publicação de 0 Negro no Pará.

No prefácio da primeira edição da obra O Negro no Pará, Arthur César Ferreira Reis apontava que a bibliografia sobre a presença africana na Amazônia era inexpressiva. Desta forma, ele procurou destacar que a bibliografia acerca da presença negra na Amazônia se apresentava inexpressivamente, pois poucos trabalhos chegaram a ser apresentados, como: O Negro na empresa colonial dos portugueses na Amazônia, de sua autoria (1961); A introdução do negro na Amazônia e Negros Escravos na Amazônia, de Nunes Pereira; o primeiro, tendo sido divulgado no Boletim Geográfico, Rio de Janeiro, 1938, e o segundo, nos Anais do X Congresso Brasileiro de Geografia, Rio de Janeiro, 1952, além de alguns elementos novos para o estudo dos batuques de Belém, de Anaíza Vergolino e Arthur Napoleão Figueiredo, pesquisa que foi propagada nas Atas do Simpósio sobre a Biota Amazônica, no Rio de Janeiro em 1967.32

Em uma carta datada de 10 de junho de 1970, enviada a Vicente Salles, Napoleão Figueiredo comenta sobre o trabalho de Anaíza Vergolino acerca de notícias históricas dos negros no Pará, estando o trabalho finalizado e aguardando publicação, pois se tratava de um trabalho volumoso e, consequentemente, com um orçamento elevado. Embora o autor desta carta não apresente o título do trabalho de Vergolino, partimos da ideia de considerar que ele esteja se referindo ao início de seus estudos sobre os batuques de Belém, iniciados na metade da década de 60, pois este trabalho - levando em consideração a interpretação das correspondências - parece ter sido realizado por partes, ou intensificado por partes. 33

\footnotetext{
32 No prefácio da primeira edição de O Negro no Pará: sob o regime da escravidão, Arthur César Ferreira Reis menciona a inexpressividade da bibliografia a respeito de estudos sobre o negro na Amazônia.

${ }^{33}$ Devemos levar em consideração o trabalho sobre os batuques de Belém que foi apresentado em 1967; o trabalho intitulado "Alguns elementos para o estudo do negro na Amazônia", de 1968, assim como, o seu texto "O Negro no Pará - a notícia histórica”, que viria a ser publicado em 1971. Nesse contexto, vale Cf.: (DIAS, 2009, p. 755). No qualo autor aborda em nota sobre a pesquisa de Vergolino e Figueiredo acerca da presença africana na Amazônia, e sobre a publicação de O Negro no Pará: sob o regime da escravidão, logo após o levantamento realizado pelos pesquisadores.
} 
Partindo da observação sobre a produção do trabalho de Salles, acerca da presença negra na Amazônia, em geral, destacamos em correspondência direcionada ao professor Napoleão Figueiredo, o fato de Salles lamentar não ter conhecido antes o seu trabalho e o de Anaíza Vergolino. Nesse sentido, ele destaca que: "Uma das coisas que lamento, quando aí estive foi constatar que durante muito tempo caminhamos por vias paralelas, dispersando esforços. Para mim teria sido extremamente útil ter conhecido a mais tempo o seu trabalho e o da Dra. Anaíza".34 E dá prosseguimento na mesma correspondência, falando sobre o Negro no Pará:

Meu ensaio sobre o Negro no Pará, há muito concluído (em termos de trabalho imediato, claro) e aguardando publicação, é resultado de pesquisa histórica em arquivos por onde me meti. E portanto, sem o saber, eu e Dra. Anaíza viajamos no mesmo barco. Verdade que não contei com a experiência e dedicação de um mestre na matéria. [...] Se nos encontrarmos em alguns pontos, de qualquer forma espero que dois ensaios sobre o mesmo tema possam despertar a atenção de outros estudiosos brasileiros que veem cultura negra apenas nas áreas tradicionais da lavoura extensiva e da mineração. ${ }^{35}$

O excerto acima evidencia certa preocupação de Salles em ter realizado o mesmo trabalho que a professora Anaíza Vergolino, porém, ele esclarece que mesmo que esses trabalhos viessem a se encontrar em algum momento, dois trabalhos sobre um mesmo tema só viria a ser benéfico, uma vez que estes incentivariam outros estudiosos ou pesquisadores a focarem a cultura negra a partir de novas perspectivas. Salles, ainda complementa seus escritos demonstrando o respeito acadêmico pelo amigo Napoleão Figueiredo, em que destaca a experiência e dedicação deste. Nessa mesma carta, observamos Salles incitando a "troca de ideias" sobre o assunto em questão, uma vez que muita coisa poderia ser "aprendida" a partir dessa troca.

Em contrapartida, Napoleão Figueiredo se posiciona a respeito da aproximação dos trabalhos apontando que tratava-se de problemas diferentes. E fez questão de salientar essas diferenças e aproximações, como poderemos perceber claramente a seguir:

34 Museu da UFPA (MUFPA). Coleção Vicente Salles (CVS). Carta de Vicente Salles a Napoleão Figueiredo Rio de Janeiro, 01/07/1970.

35 Museu da UFPA (MUFPA). Coleção Vicente Salles (CVS). Carta de Vicente Salles a Napoleão Figueiredo Rio de Janeiro, 01/07/1970. 
Pessoalmente acho que são problemas diferentes - a parte do negro na Colônia, Império e República, envolvendo assim o aspecto sociopolítico cultural e a ascensão desse negro numa sociedade de classes e a outra, o quadro atual dos cultos com sobrevivências africanas. ${ }^{36}$

E intensifica:

No primeiro, além do tratamento das fontes primárias e do levantamento bibliográfico imenso de cronistas, missionários, naturalistas viajantes, a ênfase a ser dado nesse estudo seria voltado para o fenômeno de "plantation" [...] Ao lado disso a participação do braço escravo nos diversos ciclos econômicos na Amazônia e sua integração na sociedade atual urbana ou rural. ${ }^{37}$

Dessa forma, Figueiredo procura afastar qualquer tipo de tensão que poderia vir a existir por conta da aproximação dos temas do trabalho de Salles e Vergolino, e, na verdade, procura destacar que grande parte do material que engloba este assunto foi levantado no trabalho de Anaíza Vergolino, no de Nunes Dias e no trabalho de Vicente Salles. Acreditamos que, Figueiredo, assim como Salles, procurou demonstrar os benefícios de vários estudos sobre o mesmo tema em um espaço como a Amazônia, onde Ferreira Reis - como já abordamos anteriormente - já falaria da escassez de estudos sobre a presença negra no espaço amazônico.

Ao analisarmos as correspondências entre Salles e Figueiredo, percebemos que, além da relação de amizade, que resultou em troca de cartas desde o final da década de 1960 até o final da década de 1980, é perceptível o comprometimento de ambos com o trabalho científico cultural na Amazônia. As cartas, de uma forma mais geral, nos permitiram observar um intenso diálogo, através de posicionamentos perante o trabalho de Vicente Salles, em O Negro no Pará, sobre indicações de trabalhos, favores pessoais, indicações de leituras mas, principalmente, demonstrando o respeito profissional entre dois intelectuais que procuraram ultrapassar as barreiras da distância em benefício da cultura amazônica.

\footnotetext{
${ }^{36}$ Museu da UFPA (MUFPA). Coleção Vicente Salles (CVS). Carta de Napoleão Figueiredo a Vicente Salles Belém, 12/08/1970.

37 Museu da UFPA (MUFPA). Coleção Vicente Salles (CVS). Carta de Napoleão Figueiredo a Vicente Salles Belém, 12/08/1970.
} 
Assim sendo, conseguimos perceber como O Negro no Pará foi inicialmente recebido por intelectuais como o professor Napoleão Figueiredo, seu posicionamento perante a obra e o autor, a partir da utilização do livro de Salles, em suas aulas na Universidade Federal do Pará. ${ }^{38}$ Desse modo, Figueiredo demonstrou a importância de uma obra como O Negro no Pará, a partir da inserção desta nas discussões dentro do programa de antropologia desta universidade. Salles, em outra oportunidade, responde que Ihe é grato pela utilização de seu trabalho nas aulas da universidade. Dessa forma, percebemos nesse momento a ligação que a obra teria com a academia, principalmente, no contexto da UFPA.

\section{Algumas considerações sobre os trabalhos desenvolvidos por Anaíza} Vergolino no contexto da espera e da publicação de O negro no Pará

A interlocução sobre O Negro no Pará, de modo geral, sobre os estudos da presença negra na Amazônia foram feitas de forma mais intensa com o Professor Napoleão Figueiredo, pelo menos ao que conseguimos ter acesso nesta coleção.39 Contudo, procuramos perceber alguns posicionamentos de Salles quanto ao trabalho desenvolvido por Anaíza Vergolino, a partir do exame das quatro cartas localizadas na coleção Vicente Salles. Estas correspondências foram trocadas à época da finalização de O Negro no Pará e da publicação deste.

Em uma das cartas, por exemplo, Salles agradece a Anaíza Vergolino por ter enviado o trabalho intitulado O Negro no Pará, uma notícia histórica (VERGOLINO, 1971), escrito especialmente para a Antologia de Carlos Rocque..$^{40}$ Salles destaca a questão da

${ }^{38}$ Museu da UFPA (MUFPA). Coleção Vicente Salles (CVS). Carta de Napoleão Figueiredo a Vicente Salles Belém, 13/07/1972.

39 Ao todo, foram encontradas três correspondências expedidas e uma recebida, mas nada realmente direcionado à obra de Salles, no contexto de uma análise mais intensa sobre a recepção de $O$ Negro no Pará. Porém, seria importante abordarmos uma carta escrita por Vicente Salles a Anaíza Vergolino, na qual Salles comunica o recebimento do trabalho da Antropóloga intitulado "Alguns Elementos Para o Estudo do Negro na Amazônia", e fala sobre o seu encantamento por este texto, justificado pelo fato de ignorar o trabalho que o Prof. Napoleão Figueiredo e sua assistente, na época, Anaíza Vergolino, estariam realizando. Museu da UFPA (MUFPA). Coleção Vicente Salles (CVS). Carta de Vicente Salles a Anaíza Vergolino - Rio de Janeiro, 10/07/1968.

${ }^{40}$ Trata-se do resultado das pesquisas de Vergolino sobre a proporcionalidade do contingente negro em relação à população total da Amazônia, especialmente no Pará, desde a introdução da mão de obra negra nessa região até o grau dessa miscigenação. 
representatividade deste trabalho para os estudos do negro no Brasil, onde o Pará tinha pouca expressão. Ele ainda comenta, a respeito do mesmo trabalho, que Anaíza estaria indo no "caminho certo", e que teria muito mais a revelar, e que possibilidades maiores se apresentariam, estando ela em Belém, principalmente, no que concerne à parte histórica. ${ }^{41}$

Nesse sentido, permanecendo na análise da correspondência acima, percebemos o entusiasmo de Salles perante o trabalho desenvolvido no Pará por Anaíza Vergolino e Napoleão Figueiredo, indicando as possibilidades e novidades que as pesquisas desenvolvidas em Belém poderiam gerar. Assim, nessa carta do ano de 1971, Salles aponta que existe muita coisa a ser trabalhada dentro de uma perspectiva histórica sobre o negro no Pará, destacando o fato de não se ter realizado, até aquele momento, um levantamento da imprensa paraense sobre o regime escravocrata, e a legislação do século XIX, assim como sobre um trabalho com os mocambos que ainda existiam no estado.

Observamos, em meio à análise dessas cartas, que, independentemente do fato de ambos terem caminhado na mesma direção, em algum momento, o mais importante para os pesquisadores mencionados aqui, seria de fato, incentivar a pesquisa sobre este tema na Amazônia. Nesses termos, Salles apresenta alguns pontos que soariam a favor de Anaíza, como a proximidade de fontes expressivas para se trabalhar a parte histórica ao tema do negro, assim como, usufruindo da orientação de Napoleão Figueiredo, considerado um dos grandes nomes da história da Antropologia na Amazônia.

Após termos apresentado uma breve análise das correspondências trocadas entre Salles e Napoleão Figueiredo e, em parte, com Anaíza Vergolino, no sentido de extrairmos a recepção da obra em evidência, passaremos à análise das cartas trocadas entre Salles e o jornalista Lúcio Flávio Pinto; no que diz respeito a este último, talvez tenha este propiciado um debate maior, regado a críticas mais acentuadas, como veremos a seguir.

\footnotetext{
${ }^{41}$ Museu da UFPA (MUFPA). Coleção Vicente Salles (CVS). Carta de Vicente Salles a Anaíza Vergolino - Rio de Janeiro, 26/03/1971.
} 
Algumas críticas mais acentuadas: as cartas trocadas entre Lúcio Flávio Pinto e Vicente Salles

[...] se situe no meu ponto de vista - que é o de profundo respeito ao crítico. Uma literatura sem críticas - e vou agora me derramar em conceitos? - não pode ter vitalidade, tampouco expressão. Toda obra é para ser discutida. Só podemos acrescentar alguma coisa no conhecimento a partir do questionamento do que foi estabelecido. ${ }^{42}$

O excerto destacado acima evidencia claramente o posicionamento crítico de Salles perante a produção escrita e de leitura em geral. Trata-se de parte de sua resposta às críticas do jornalista paraense Lúcio Flávio Pinto à pesquisa de Salles, principalmente, quanto a sua metodologia. O que o jornalista procurou passar a Salles foram as angústias de um leitor diante do resultado de um estudo, e desta forma, ele expõe suas razões a partir da leitura de O Negro no Pará, como poderemos perceber a seguir: "Como você mesmo diz, há 'pouca abundância' documental. Aceita essa premissa, acho que as mais estimulantes 'pistas' estão no seu 'O Negro no Pará' e foi justamente nele, como você deve ter notado que centrei o meu trabalho sobre a Cabanagem". ${ }^{43}$

Desta forma, a partir de uma leitura geral das cartas de Lúcio Flávio a Vicente Salles, percebemos que suas críticas constantes ao livro de Salles partiram do seu interesse pelo tema da revolução cabana. Nesse sentido, a partir de seu diálogo com Salles, podemos assinalar a produção de um trabalho sobre a Cabanagem que este jornalista desenvolveu ou estava desenvolvendo no final da década de 1970. Mas sua opinião sobre a parte direcionada ao movimento cabano, dentro do livro O Negro no Pará foi bastante direta, porém, sempre reconhecendo a importância da interpretação desenvolvida por Salles. Para Lúcio Flávio, apesar de "episódico", o trabalho de Salles se apresentou com densidade, inclusive em comparação as pesquisas que o próprio Lúcio Flávio vinha desenvolvendo na época.

\footnotetext{
${ }^{42}$ Museu da UFPA (MUFPA). Coleção Vicente Salles (CVS). Carta de Vicente Salles a Lúcio Flávio Pinto Brasília, 19/12/78.

43 Museu da UFPA (MUFPA). Coleção Vicente Salles (CVS). Carta de Lúcio Flávio Pinto a Vicente Salles Belém, 11/12/1978.
} 
No sentido de justificar sua avaliação crítica direcionada à Cabanagem perante o amigo, diz ver - à época da leitura do livro de Salles, e do desenvolvimento sobre o seu trabalho - a Cabanagem com a curiosidade de um jornalista, e claro, pela questão da informação, diferentemente de Vicente Salles, que a viu como historiador. Assim, Lúcio Flávio descreve o desenvolvimento do trabalho do amigo historiador, uma vez que nesse contexto, Salles "tem desenvolvido um trabalho lento, parcelado, difícil, mas sistemático. [...] Respeito-o não por interpretações bibliográficas, mas por uni-las ao trabalho de revelação documental”, mesmo considerando que alguns fenômenos e fatos referentes ao movimento, talvez, nunca viessem a ter uma "base documental definitiva". E continua na mesma correspondência:

Não considero, como você também não deve considerar, que seja a resposta definitiva. Mas mesmo sem abrir muito o referencial documental, você foi o que levou mais adiante a interpretação da Cabanagem, quem ordenou melhor a documentação, quem leu melhor os interpretadores. [...] Situou o problema numa condição de classe. E desmistificou a liderança "citadina" do movimento, abrindo os nossos olhos para os líderes populares [...] você levantou aspectos importantes, como a da transmissão oral e não escrita da ideologia. Essa é uma observação vital $[. ..]{ }^{44}$

Percebemos, então, não só no fragmento acima apresentado, mas como no início desta carta, a valorização e o respeito pelo trabalho de Salles, pelos ensinamentos e informações históricas - destacando a parte direcionada ao movimento Cabano -, resultado de um intenso e prolongado trabalho de pesquisa desenvolvido por Salles. Lúcio Flávio inclusive faz uma observação a respeito da metodologia de Salles, destacando que o folclorista trabalha com aspectos importantes como a transmissão oral da ideologia. Porém, em carta anterior, Salles já se justificaria através de O Negro no Pará diante da crítica de Lúcio Flávio, quando o jornalista apontou que suas análises resultariam mais em deduções teóricas. Na carta de 26 de novembro de 1978, a respeito disso, Salles apontou:

Na Cabanagem a ideia da abolição da propriedade privada esteve na cabeça de caboclos e de negros, como demonstro em O Negro no Pará,

\footnotetext{
44 Museu da UFPA (MUFPA). Coleção Vicente Salles (CVS). Carta de Lúcio Flávio Pinto a Vicente Salles -
} Belém, 11/12/1978. 
considerando mesmo - não intuitivamente, como você observou - mas com os documentos que me foram dados examinar, que os ideais que impulsionavam os rebeldes tiveram expressão ideológica efetiva, concreta, principalmente nas lideranças populares, esmagadas, afinal, pelos chefes cabanos. ${ }^{45}$

No contexto da mesma carta, Salles se defende falando que sempre trabalhou sobre os documentos e que se fossem tiradas as transcrições da obra em questão, ela se apresentaria com um valor escasso. ${ }^{46}$ No intuito de alargarmos as discussões sobre este diálogo, percebemos que há um leitor ferozmente atento e crítico e um escritor procurando aprimorar cada vez mais o seu trabalho diante dos seus leitores, diga-se de passagem, um escritor que sempre procura lembrar-se das suas dificuldades no que concerne ao desenvolvimento de pesquisas em seu tempo, e, sempre esclarecendo as fontes que foram possíveis de se alcançar. No sentido de percebermos os debates entre escritor e leitor que presenciamos a partir da leitura das cartas, seria pertinente destacarmos que a leitura é, na realidade, uma ativa elaboração de significados dentro de um sistema de comunicação, como bem aponta o historiador Robert Darnton (1986). ${ }^{47}$

Como enfatizamos acima, através das próprias palavras de Salles, o autor procurou analisar em O Negro no Pará, o engajamento do negro no movimento cabano, comprovando através de documentação a politização dos escravos em meio à luta cabana, como podemos observar no ofício que foi citado por Domingos Antônio Raiol, e utilizado por Salles. Segundo Vicente Salles, as ideias que foram lançadas pelo frei Luís Zagalo, por Filipe Patroni e Batista Campos tiveram uma abrangente reverberação entre os escravos, porém, ressaltou que houve outros líderes populares que exerceram considerável influência entre eles, e que as ideias de emancipação não foram

\footnotetext{
45 Museu da UFPA (MUFPA). Coleção Vicente Salles (CVS). Carta de Vicente Salles a Lúcio Flávio Pinto Brasília, 26/11/1978.

${ }^{46}$ Museu da UFPA (MUFPA). Coleção Vicente Salles (CVS). Carta de Vicente Salles a Lúcio Flávio Pinto Brasília, 26/11/1978.

47 No texto intitulado "Os leitores respodem a Rosseau: A fabricação da sensibilidade romântica", Darnton acaba por definir o significado da leitura, na busca por procurar entender como os franceses liam os livros no século XVIII, como pensavam estes leitores, como participavam da transmissão do pensamento pelos símbolos impressos, a partir de seu estudo com as correspondências que foram enviadas a Rousseau, para o estudo da recepção de La nouvelle Héloise.
} 
contempladas pelos "chefes supremos" da revolução, foram, na verdade, reprimidas (SALLES, 1988, p. 266-267).

Partimos dessas colocações expostas acima, para apresentarmos a justificativa de Salles diante das críticas de Lúcio Flávio Pinto, no que diz respeito à documentação utilizada na obra em questão. Nesse sentido, Vicente Salles destaca que: "Concluí, em O Negro no Pará, que os ideais da Cabanagem foram traídos por seus próprios líderes, isto é, aqueles que controlaram a massa. O grande desafio, para o historiador, é a identificação das lideranças populares". ${ }^{48}$ Explicou Salles em seu livro que, nesse período, a população escrava tinha um volume significativo, e que sua mobilização exigia diversos líderes. Observamos que para a citação dos nomes de negros que atuaram como líderes em algum momento nesse motim, Salles se utiliza, principalmente, pelo que ele chamou de "via indireta" como Os Motins Políticos, de Raiol.

Ainda sobre a questão das “deduções" presente no livro de Salles, especialmente no que diz respeito à Cabanagem, Lúcio Flávio diria que talvez tenha sido mal interpretado, pois sua angústia se reportaria ao fato de existir "[...] muita frase de efeito sem explicitação factual", e para isso destaca as referências ao estudo do movimento cabano, como, por exemplo, o de Jorge Hurley, uma vez que este intelectual aponta que a ideologia do movimento terminou com a morte de Batista Campos, não problematizando a questão. ${ }^{49}$ Logo, Lúcio Flávio, referia-se a questões mais específicas como a mencionada há pouco, e não a algo generalizado, uma vez que, o jornalista era conhecedor da escassez dos documentos e sobre as incógnitas a respeito da Cabanagem, visto que, como mencionamos anteriormente, ele estava trabalhando intensamente neste tema.

Lúcio Flávio Pinto está entre as personalidades que mantiveram contato considerável com Vicente Salles. A correspondência expedida - na verdade - as cópias ou

\footnotetext{
${ }^{48}$ Museu da UFPA (MUFPA). Coleção Vicente Salles (CVS). Carta de Vicente Salles a Lúcio Flávio Pinto Brasília, 26/11/1978.

49 Henrique Jorge Hurley está situado entre os principais narradores do movimento cabano. Foi militar e formou-se em Direito em 1910. Como intelectual dedicou-se aos estudos históricos e ao folclore paraense, é autor de A Cabanagem e Traços Cabanos. Cf. (RICCl, 2007, p. 309-328). Ver, também: Museu da UFPA (MUFPA). Coleção Vicente Salles (CVS). Carta de Lúcio Flávio Pinto a Vicente Salles - Belém, $11 / 12 / 1978$.
} 
rascunhos delas são da década de 1970, assim como as recebidas - embora, o jornalista não datasse a maior parte delas (pelo menos as que constam no acervo) - período em que O Negro no Pará foi publicado pela primeira vez. No geral, as cartas que foram manuseadas, nos permitiram fazer algumas considerações. As críticas de Lúcio Flávio eram vistas por Salles como "provocações que animam a gente",50 embora, alguns diálogos apareçam com certa tensão. Assim como outros amigos, Lúcio Flávio Pinto foi responsável por amenizar a falta de notícias a respeito do meio cultural de Belém, do Pará, e da região norte, uma vez que, aqui e ali surge um agradecimento pela atualização das notícias da "terrinha". ${ }^{51}$

\section{Considerações finais}

Procuramos, ao longo deste texto, apresentar passos mais específicos acerca da trajetória intelectual de Vicente Salles, buscando situar este intelectual em seu espaço e seu tempo, a partir de um "momento-chave" de sua vida; neste caso, a produção de sua obra mais proeminente. Entrevistas, correspondências, livros, foram as principais fontes, que utilizamos, tendo em vista obtermos uma análise mais intensa na execução deste trabalho. Da mesma forma, procuramos demonstrar como algumas personalidades se tornaram essenciais para a compreensão do engajamento político e cultural de Vicente Salles, como Bruno de Menezes e Edison Carneiro.

O Negro no Pará se tornou referência a respeito dos estudos sobre a presença negra na Amazônia, por inúmeros fatores que foram mencionados ao longo destas páginas, mas o fato de Salles ter trabalhado com uma visão não vitimizadora do negro é um ponto destacável nesse percurso. Assim, para o nosso intelectual, a participação da "massa" escrava colocou-se como um dos pontos mais relevantes no estudo sobre o movimento cabano, visto que o engajamento do negro ao movimento não foi feito de forma "anárquica" principalmente, sem nenhum tipo de orientação. Como foi dito

\footnotetext{
${ }^{50}$ Museu da UFPA (MUFPA). Coleção Vicente Salles (CVS). Carta de Vicente Salles a Lúcio Flávio Pinto Brasília, 09/11/1978.

${ }^{51} \mathrm{~A}$ partir das cartas podemos falar sobre os intelectuais e sua rede de sociabilidade (no caso, parte dela), sobre o entendimento da circulação das ideias, compreensão de determinada dinâmica e de seus posicionamentos.
} 
anteriormente, estes aspectos foram tratados inicialmente na forma de um texto publicado em 1968 e intensificado posteriormente em O Negro do Pará, sob a forma de livro em 1971; isto posto, o livro se difere por problematizar e se posicionar sobre toda a “contradição" a respeito dos estudos direcionados ao Movimento Cabano até então, principalmente ao que foi narrado por Domingos Antônio Raiol.

Cabe assinalar que os três receptores-decodificadores analisados aqui (Napoleão Figueiredo, Anaíza Vergolino e Lúcio Flávio Pinto) possuem formação acadêmica sólida. Isso fez com que, não obstante a suposição por parte de Salles de que a obra seria absorvida por um público essencialmente acadêmico, o elevado grau de formação e instrução desses três receptores-decodificadores, simétrico ao do próprio produtorcodificador (Vicente Salles) fez com que não houvesse "mal-entendidos" do teor de mensagem codificada por Salles nos termos de uma forma discursiva específica, no que diz respeito à recepção-decodificação dos seus interlocutores aqui explorados.

Para este texto, lançamos mão especialmente das correspondências expedidas e recebidas, o que deve ser repisado, no intuito de celebrar a antiga prática de guardar duplicatas. Essa prática nos permitiu compreender, em parte, sobre a forma de produção do livro, e de uma maneira mais detida, sobre a recepção do mesmo pelos pares de Salles, no sentido de compreender como um - dentre seus inúmeros livros - foi acolhido, no meio acadêmico paraense, a partir dos escritos de intelectuais como Napoleão Figueiredo, Lúcio Flávio Pinto, e em certa medida de Anaíza Vergolino, e do próprio Vicente Salles que, muito se preocupou em responder aos questionamentos de seus leitores.

\section{Referências}

ALBUQUERQUE, Wlamira; FRAGA FILHO, Walter. Uma história do negro no Brasil. Salvador: Centro de Estudos Afro-Orientais; Brasília: Fundação Cultural Palmares, 2006.

BEZERRA NETO, José Maia. Do vazio africano à presença negra: historiografia, fontes e referências sobre a escravidão africana na Amazônia. 2010. (mimeo). 
BOURDIEU, Pierre. A ilusão biográfica In: AMADO, Janaína; FERREIRA, Marieta de Moraes (Org.). Usos \& abusos da história oral. Rio de Janeiro: Editora FGV, 2006, p.183-191.

BURNS, E. Bradford. A Report from Brazil: Recent Publishing in Amazonas. Luso-Brazilian Review, v. IV, n. 01, p.111-116. Jun.1967.

CARDOSO, Ciro Flamarion. Economia e sociedade em áreas coloniais periféricas: Guiana Francesa e Pará, 1750-1817. Rio de Janeiro: Edição Graal, 1984.

CARNEIRO, Edison. A conquista da Amazônia. Rio de Janeiro: Ministério da Aviação e Obras Públicas/Serviço de Documentação. Coleção Mauá, 1956.

CHARTIER, Roger (Org.). Práticas de leitura. São Paulo: Estação Liberdade, 1996.

DARNTON, Robert. O Grande massacre de gatos, e outros episódios da história cultural francesa. Rio de Janeiro: Graal, 1986.

DIAS, Antônio Maurício. Pesquisas antropológicas urbanas no "paraíso dos naturalistas". Revista de Antropologia, São Paulo: USP, v. 52, n.2, p. 735-761, 2009.

FIGUEIREDO, Napoleão; VERGOLINO, Anaíza. Alguns Elementos novos para o estudo dos batuques em Belém. Atas do Simpósio da Biota Amazônica. Rio de Janeiro, v. 2. Antropologia, p. 101-122, 1967.

FIGUEIREDO, Napoleão. A Presença africana na Amazônia. Revista Afro-Ásia. Salvador, UFBA, n. 12, p.145-160, 1976.

FIGUEIREDO, Aldrin Moura de. A Cidade dos encantados: pajelança, feitiçaria e religiões afro-brasileiras na Amazônia, 1870-1950. Belém: EDUFPA, 2008.

GALVÃO, Eduardo. Santos e visagens: um estudo da vida religiosa do Itá, Baixo Amazonas. $2^{\text {a }}$ ed. São Paulo, Ed. Nacional; Brasília, INL, 1976 [1955].

GALVÃO, Walnice Nogueira; GOTLIB, Nádia Battella (Orgs.). Prezado senhor, prezada senhora: estudo sobre cartas. São Paulo: Companhia das Letras, 2000.

GOMES, Ângela de Castro. Escrita de si, escrita da história: a título de prólogo. In: GOMES, Ângela de Castro (Org.). Escrita de si, escrita da história. Rio de Janeiro: FGV, 2004, p. 0724 .

GOMES, Ângela de Castro. Nas malhas do feitiço: o historiador e os encantos dos arquivos privados. Revista Estudos Históricos , v. 11, n. 21, p. 121-127, 1998. 
HALL, Stuart. Da diáspora: Identidades e mediações culturais. Belo Horizonte, UFMG, 2003.

LIMA, Luciano. Os Motins políticos de um Ilustrado liberal: história, memória e narrativa na Amazônia em fins do século XIX. 2010. Dissertação (Mestrado em História) Universidade Federal do Pará, Programa de Pós em História Social da Amazônia, Belém, 2010.

MAFRA, Alessandra. Construindo um acervo: história, intelectualidade e colecionismo em Vicente Salles. In: MENEZES, Lená Medeiros de; TRONCOSO, Hugo Cancino; MORA, Rogelio de la. (Org.). Intelectuais na América Latina: pensamento, contextos e instituições. Dos processos de Independência à Globalização. Rio de Janeiro: LABIME/UERJ, 2014, v. 1, p. 62-77.

MALATIAN, Teresa. Cartas: narrador, registros e arquivos. In: PINSKY, Carla Bassanezi; LUCA, Tânia de. O Historiador e suas fontes. São Paulo: Contexto, 2009, p. 195-221.

MAUÉS, Raymundo Heraldo. Uma outra “invenção” da Amazônia: religiões, histórias, identidades. Belém: Edições CEJUP, 1999.

MOTT, Luiz. A propósito de três livros sobre o negro brasileiro. Revista de História, USP, n. 96,1973 .

OLIVETO, Karla Aléssio. Vicente Salles: trajetória pessoal e procedimentos de pesquisa em música. 2007. Dissertação (Mestrado em Música) - Universidade de Brasília, Brasília, 2007.

REIS, Daniel Aarão. Ditadura militar, esquerdas e sociedade. Rio de Janeiro: Jorge Zahar Editor, 2000.

RICCI, Magda. Folclore, Literatura e História: a trajetória de Henrique Jorge Hurley. In: FONTES, Edilza Joana de Oliveira; BEZERRA NETO, José Maia (Orgs). Diálogos entre história, literatura e memória. Belém: Paka-Tatu, 2007, p. 309-328.

ROLLEMBERG, Denise. Nômades, sedentários e metamorfoses: trajetória de vidas no exílio. In: REIS, Marcelo Ridenti et al. (Orgs.). $O$ golpe e a ditadura militar: quarenta anos depois (1964-2004). Bauru, São Paulo: Edusc, 2004, p.277-296.

SALLES, Vicente. A Cabanagem, os escravos e os engenhos. Brasil Açucareiro, Rio de Janeiro, v. 36, n. 05, p.33-38, maio/1968.

SALLES, Vicente. Edison Carneiro, e o folclore do negro. Edição do Autor: Brasília, 1990 [1988]. 
SALLES, Vicente. O Negro no Pará: sob o regime da escravidão. $2^{\text {a }}$ Ed. Brasília/Belém: Ministério da Cultura/Secretaria de Estado da Cultura/Fundação Cultural do Pará "Tancredo Neves", 1988 ( $1^{\mathrm{a}}$ Ed. em 1971, publicada pelas Editoras da UFPA e da FGV, e $3^{\text {a }}$ Ed. em 2005, publicada pelo IAP).

SALLES, Vicente. Um retrospecto - memória. $2^{\text {a }}$ edição revista e ampliada. Brasília: MicroEdição do Autor, 2007.

SALLES, Vicente. Memorial da Cabanagem: esboço do pensamento políticorevolucionário no Grão-Pará. Belém: CEJUP, 1992.

SCHWARTZ, Stuart. Escravos, roceiros e rebeldes. Bauru, São Paulo: EDUSC, 2001.

VERGOLINO , Anaíza . O Tambor das flores: uma análise da Federação Espírita Umbandista e dos Cultos Afro-Brasileiros do Pará (1965-1975). 1976. Dissertação (Mestrado em Antropologia) - Universidade Estadual de Campinas, Programa de PósGraduação em Antropologia, Campinas, 1976.

VERGOLINO, Anaíza. O Negro no Pará, uma notícia histórica. In: ROCQUE, Carlos (Org.). Antologia da cultura Amazônica, v. VI, 1971, p. 17-33. 